\title{
Willingness of Tax Amnesty Participation Based on Financial Audit Quality
}

\author{
Permata Ayu Widyasari ${ }^{1}$, Celina Tashya Evangelista ${ }^{2}$, Yie Ke Feliana ${ }^{3}$ \\ \{permataayu@staff.ubaya.ac.id ${ }^{1}$ \} \\ University of Surabaya, Indonesia ${ }^{1,2,3}$
}

\begin{abstract}
Tax amnesty is an Indonesian government program which company may reveal its hidden asset. By paying redemption money, the taxpayer can reveal its hidden asset without getting the typical administrative sanction of taxation. It turned out that many companies hiding its asset participated in this program. That condition raises the question regarding audit quality of the financial statement of those companies. Audit quality is proxied by the accounting firm's reputation, industry specialization, and tenure. The research shows that the accounting firm's reputation had a significant negative impact on participation in the tax amnesty program in 2016, 2017, or both, and the amount of restatement regarding tax amnesty program. BIG - 4 accounting firms are associated with better audit quality. Consequently, the company which audited by BIG-4 are less likely to participate in tax amnesty. In addition, leverage as control variable had a significant negative impact on participation in the tax amnesty program.
\end{abstract}

Keywords: audit quality, accounting firm's reputation, tax amnesty, restatement.

\section{Research Background}

The effectiveness of tax amnesty, in the long run and short run, is still debatable yet it is being used as a fiscal policy for a national income source of a country. In the short run, it might give the additional revenue of a country, but in the long run it might potentially reduce the future tax compliance [1]

Development of Indonesia relies on tax payment. More than $80 \%$ of Indonesia's budging is obtained from tax payment ${ }^{1}$. When a particular citizen does not participate in paying tax by hiding its asset, it violates the fairness and justice principles of the Indonesian tax system. Moreover, there are Indonesia citizens investing their hidden asset abroad. That hidden asset presumably can be used for Indonesian development.

The hidden assets are supposed to be imposed with income tax (the normal rate is progressive from 5\% until 30\%) plus its sanction 2\% per month (maximum 24 months) ${ }^{2}$. That condition makes the taxpayer reluctant to reveal their hidden asset. It is needed a policy which gives assurance about the legal certainty and safety of the taxpayer when they reveal their hidden asset.

\footnotetext{
${ }^{1}$ Based on Indonesian Budgeting, 2018

${ }^{2}$ Based on Indonesia Income - Tax Law 2008 article 17
} 
An amnesty usually permit a person or an entity to reveal its hidden asset, without imposed regular tax sanction and regulation [2]

On 2016, the Indonesian government launched a tax amnesty policy. By paying redemption money, the taxpayer can reveal its hidden asset without getting the typical administrative sanction of taxation. The proposed rate of redemption is lower than the normal rate of tax income plus its administrative sanction, which is only $0.5 \%-10 \%$. In addition, tax amnesty participant will be granted the omission of tax payable, administrative sanction, tax inspection and termination of ongoing tax inspection ${ }^{3}$.

As fiscal policy, Indonesian tax amnesty has several purposes, firstly, to accelerate the economic growth through increasing domestic liquidity, strengthening the rupiah exchange rate, lowering interest rate, and increasing investment. Secondly, construct the valid, transparent, and integrated database and tax system. Thirdly, increase tax revenue for Indonesian capital expenditure.

For a delinquent taxpayer, willingness to participate in tax amnesty will be driven by cost of non-compliance, including tax inspection and future double tax fines. [3]

In Indonesia, after the termination of the tax amnesty period, if the government find any hidden asset, it will be imposed tax fine until $200 \%$.

Indonesian tax amnesty has been done from September 2016 - March 2017. It gave the opportunity for the taxpayer to expose its hidden asset based on Annual Tax Return of the tax year 2015. For the listed company, if the asset is hidden in the Annual Tax Return of 2015, automatically it is hidden in the 2015 financial statement. Consequently, the listed company participating in tax amnesty will restate its 2015 financial statement. The result shows that 131 listed companies participated in a tax amnesty program.

Even though the financial statement has been audited, when the listed company participate in tax amnesty and reveal its hidden asset in significant amount, the company must restate its financial statement. Restatement of audited financial statement can be an indication that the previous audited financial statement did not report the true condition about auditee's financial condition or the auditor might have been missed the material misstatement. It raised an intriguing question about the audit quality of the financial statement, especially when the financial statement gets an unqualified opinion.

International standard on auditing 200 regulates that during expressing its financial statements' opinion, the auditor must be able to obtain reasonable assurance that the financial statements are free from material misstatement, whether due to fraud or error [4].

Audit quality can be clarified as auditor's ability to detect and report misstatement and meet the legal and professional requirement [5]. Based on the supply side, the audit firm will perform higher audit quality when it has more technical knowledge of a client's industry [6]. Big 4 auditors (i.e., PwC, EY, Delloitte, and KPMG) are multinational accounting firms which are organized as national partnerships with national administrative offices. In order to maintain its quality, they established standardized audit programs and applied knowledge-sharing practices. Consequently, the Big 4 tend to invest heavily in staff recruitment and training, and information technology [7].

This research aims to observe whether audit quality affects tax amnesty participation. The research defines audit quality as auditor's reputation, auditor's industry specialization, and auditor's tenure. The research contributes a finding that company which is audited by BIG 4 audit firm will impose the higher audit quality, consequently the company will be less likely to participate in tax amnesty.

${ }^{3}$ Basen on Indonesian Tax Amnesty Law 2016 


\section{Hypothesis Development}

Several previous researchers have shown the indication of audit quality of the Big - 4 accounting firms. In order to maintain its quality, regarding the restraint of abnormal accruals, the Big 4 are more likely to issue an unclean opinion. It reflects that the Big 4 provides more conservative accounting in order to prevent future litigation and possible reputation damages [7]. Regarding financial standard compliance, a company which audited by Big-5+2 auditor are exhibit greater IFRS compliance [8]. In order to reduce information asymmetry, manager from "less secretive" or more transparent company is more committed to higher-quality audits by choosing a Big four auditors [9]. Moreover, the company which located in countries with high corporate ethical values are more likely to hire a Big four auditor [10]. Big 4 auditors are persistent in maintaining their good reputation and conducting a thorough audit that will decrease the likelihood of audit failures [11]

In Indonesia, the top - tier accounting firm is associated with Big-4 (e.g. PwC, Delloitte, KPMG, and EY). Based on previous studies, Big 4 are associated with high audit quality, moreover, Big 4 auditors eager to protect their reputation by not involving in future audit failures, therefore they audit their client thoroughly in the engagement period. This implied that companies audited by Big 4 auditors in 2015 would less likely to participate in tax amnesty because of the higher audit quality.

H1: Auditors' reputation negatively related to participation in tax amnesty program, participation in tax amnesty program in 2016, 2017, or both, and the amount of restatement caused by tax amnesty.

Previous studies show that industry specialized auditors provided higher audit quality. Auditee of industry specialized had a higher ranking from financial analysts in disclosure quality [12]. Industry-specialized auditor also gave a higher assurance level [13]. It leads to a hyphotesis that auditee of industry specialized auditors will less likely to participate in tax amnesty program since they had been imposed by higher audit quality compare with non industry specialized auditors

H2: Auditors' industry specialization negatively related to participation in the tax amnesty program, participation in tax amnesty program in 2016, 2017, or both, and the amount of restatement caused by tax amnesty.

Longer audit tenure will impact an audit committee's effectiveness and decrease audit quality [14]. Audit quality decreased in longer tenure because of auditors' reluctance to issue going concern opinion. It can be concluded that prolong audit tenure with clients could be the cause of lower independence and objectivity due to familiarity threat [15]. When a client has good control in financial reporting, accurate, low risk and integrity and competence top management, automatically, in the future audit engagement, the professional skepticism will decline with tenure. On the other hand, a new audit firm will have a new perspective and bear skepticism [16]. It leads that long auditor tenure leads to a reduction in audit quality. Consequently, the auditee which has been audited by long tenure accounting firm will be audited by less quality so they will be more likely to participate in the tax amnesty program.

$\mathrm{H} 3$ : Audit tenure positively related to participation in the tax amnesty program, participation in tax amnesty program in 2016, 2017, or both, and the amount of restatement caused by tax amnesty. 


\section{Methodology and Sample Selection}

\subsection{Dependent Variable}

\section{Participation in Tax Amnesty (RESTATE/NOT)}

In order to test the Hypothesis, whether or not the company participates in tax amnesty during the tax amnesty period, the research uses a binomial logistic model. If the company participates in tax amnesty, one would be given. If not, it would be 0 .

\section{Year of Participation in Tax Amnesty (RESTATE_CATEGORIES)}

Regarding hypothesis testing for robustness test, the research uses a multinomial logistic model. It would be inputted 0 when the company didn't participate in tax amnesty, one if the company participated in 2016, two if the company participated in 2017, and three if the company participated in both 2016 and 2017.

\section{Tax Amnesty Restatement Amount (RESTATE_AMOUNT)}

Robustness test of the research will test of the amount of tax amnesty restatement amount. The research will use multiple linear regression method. The restatement amount is regarding the revealing of a hidden asset in tax amnesty. This amount is disclosed in Notes of Financial Statement.

\subsection{Independent Variable}

\section{Auditor's Reputation (REPUT)}

If the auditor is Big 4 auditor, the auditor would be seen as having a good reputation, and it would be given a value of 1 . Otherwise, it would be given a value of 0 .

\section{Auditor's Industry Specialization (SPEC)}

Auditor's industry specialization would be measured using the market share with regard to the total assets of the company [17].

SPEC $=($ Total asset of all clients audited by a particular audit firm in a particular industry)/(Total assets of all company in the industry)

\section{Audit Tenure (TENURE)}

Tenure is measured by counting backward of how long a signing audit partner has audited the company from 2015. Instead of counting the accounting firm tenure, this research uses audit partner tenure. Audit partner is used as the indicator because the audit partner is seen as the one who can build a relationship with a client that can result in familiarity and biasness in giving an opinion. Moreover, the Indonesian Government's Law No.20 in 2015 article 11 stated the rules regarding rotation of audit partner for every five years, not public accounting firm's rotation.

\subsection{Control Variable}

The research uses several variables to control the model, including firm size, leverage, number of operation segments, and number of subsidiaries. We also incorporate the type of industry to mitigate the potential confounding effects across industries. 


\subsection{Sample Selection}

Sample selection used non probability sampling method that is purposive judgmental sampling. There are three criteria used for sample of this study, (1) companies must be listed in Indonesia Stock Exchange in 2015-2017, (2) companies must also have already published financial statements 2015-2017, (3) the financial statement must be disclosed in Rupiahs. Lastly, the financial statement must consist of all the information needed in the model. This process yielded 404 firms for binomial and multinomial logistic regression and 385 firms for multiple linear regressions. We used 2016 and 2017 data for dependent variables and 2015 data for independent and control variables.

\subsection{Empirical Model}

In this study using three regression models, i.e binomial logistis regression, multinomial logistic regression and multiple linear regression. The model is $\mathrm{Y}$ as a function of (REPUT,TENURE, SPEC, SIZE, LEV, SEGMENT, SUBS, DMANUF, DFIN, DSERV, DTRADING). Y is a dependent variable, which one of these: (1) RESTATE/NOT, a dummy variable set to 1 if company participates in the tax amnesty program and 0 otherwise, (2) RESTATE_CATEGORIES, a multinomial variable set to 0 if the company didn't participate in tax amnesty, 1 if it participated in 2016, 2 if it participated in 2017, and 3 if it participated in both 2016 and 2017, (3) RESTATE_AMOUNT, restatement amount caused by tax amnesty, which is transformed using Johnson transformation. REPUT is a dummy variable set to 1 if Big 4 and 0 otherwise. SPEC is market share with regards to the company's total assets. TENURE is the tenure of signing audit partner. SIZE is a log of total assets. LEV is the total debt/total equity. SEGMENT is a number of operation segments. SUBS is a number of subsidiaries. DMANUF is a dummy variable set to 1 if the company operate in manufacture industry and 0 otherwise. DFIN is a dummy variabel set to 1 if the company operate in the financial industry and 0 otherwise. DSERV is a dummy variabel set to 1 if company operate in the others service industry, and 0 otherwise. DTRADING is a dummy variabel set to 1 if the company operate in the trading industry, and 0 otherwise.

\section{Result and Discussion}

\subsection{Binomial Logistic Regression}

Hosmer and Lemeshow's Goodness of Fit of this study is 0.269 , which is lower than 0.05 , indicating the fitness of the model. Nagelkerke R Square of this study is 0.258 , meaning independent and control variables explained $25,8 \%$ of variations of the dependent variable. 
Table 1. Binomial Logistic Regression Result

\begin{tabular}{lccr}
\hline Independent Variable & B & Sig. & Exp(B) \\
\hline REPUT & -1.594 & $0.000^{*}$ & 0.203 \\
TENURE & 0.033 & 0.830 & 1.033 \\
SPEC & 0.232 & 0.839 & 1.261 \\
SIZE & -0.269 & 0.133 & 0.764 \\
LEV & -0.113 & $0.050^{*}$ & 0.893 \\
SEGMENT & 0.033 & 0.679 & 1.033 \\
SUBS & 0.042 & $0.000^{*}$ & 1.043 \\
DMANUF & -0.398 & 0.366 & 0.672 \\
DFIN & 0.281 & 0.571 & 1.324 \\
DSERV & 0.264 & 0.532 & 1.302 \\
DTRADING & 0.543 & 0.300 & 1.722 \\
Constant & 3.325 & 0.115 & 27.792 \\
\hline
\end{tabular}

Based on the estimated parameter, Equation (1) is:

$\mathrm{y}=\mathrm{p} /(1-\mathrm{p})=e^{\wedge}(3.325-1.594$ REPUT +0.033 TENURE +0.232 SPEC -0.269 SIZE $0.113 \mathrm{LEV}+0.033$ SEGMENT +0.042 SUBS -0.398 DMANUF +0.281 DFIN +0.264 DSERV +0.543 DTRADING)

REPUT is significant negative, which implies that companies audited by Big 4 had a lower probability of 0.203 times $(e-1,594)$ in participating the tax amnesty program compare with companies audited by non-Big 4. Meanwhile, leverage and subsidiaries have a significant effect. Companies that have lower leverage have a higher probability of participating in a tax amnesty program. On the other hand, the higher the number of subsidiaries, the higher the probability of participating in the tax amnesty program.

\subsection{Multinomial Logistic Regression}

Table 2. Multinomial Logistic Regression Result - Significant Only

\begin{tabular}{cllrr}
\hline \multirow{2}{*}{ RESTATE_CATEGORIES } & & B & Sig. & \multicolumn{2}{c}{ Exp(B) } \\
\hline \multirow{2}{*}{ ( tax amnesty in 2016) } & SUBS & 0.045 & 0.000 & 1.046 \\
2 (tax amnesty in 2017) & [REPUT $=0]$ & 1.494 & 0.001 & 4.453 \\
3(tax amnesty in 2016 \& 2017) & [REPUT $=0]$ & 2.141 & 0.011 & 8.505 \\
& SUBS & 0.049 & 0.000 & 1.050 \\
& [REPUT $=0]$ & 1.489 & 0.012 & 4.433 \\
\hline
\end{tabular}

$\operatorname{Ln} \frac{P(2016)}{P(\text { tidak restate })}=3.412+1.494$ REPUT +0.187 TENURE- 0.127 SPEC -0.3 SIZE

- 0.103 LEV + 0.013 SEGMENT + 0.045 SUBS + 0.156 DMANUF - 0.71 DFIN -

0.709 DSERV - 1.040 DTRADING 


$$
\begin{aligned}
& \operatorname{Ln} \frac{P(2017)}{P(\text { tidak restate })}=-3.659+2.141 \text { REPUT }-0.639 \text { TENURE + 0.429 SPEC }-0.022 \\
& \text { SIZE }-0.132 \text { LEV + 0.143 SEGMENT + 0.004 SUBS + 0.463 DMANUF + } 0.093 \\
& \text { DFIN + 0.880 DSERV + 0.106 DTRADING }
\end{aligned}
$$$$
\begin{aligned}
& \operatorname{Ln} \frac{P(2016 \text { dan } 2017)}{P(\text { tidak restate })}=-0.092+1.489 \text { REPUT }+0.030 \text { TENURE }+0.879 \mathrm{SPEC}-0.318 \\
& \text { SIZE }-0.13 \mathrm{LEV}-0.011 \mathrm{SEGMENT}+0.049 \mathrm{SUBS}+0.825 \mathrm{DMANUF}+0.571 \mathrm{DFIN} \\
& -0.016 \text { DSERV }+0.083 \text { DTRADING }
\end{aligned}
$$

Table 2 shows the significant result of multinomial logistic regression result based on equation 2, 3, and 4. Prior to this, we already test the fitness of the model. REPUT $=0$ has a significant positive impact on category 1,2 , and 3 . This means companies audited by non-Big 4 auditors have a higher probability of participating in a tax amnesty program in 2016, 2017, or both (2016 and 2017) compare with companies audited by the Big-4. Meanwhile, SUBS has a significant positive impact. This means an increase in the number of subsidiaries would increase the probability of company participating in a tax amnesty program in 2016 and both years.

\subsection{Multiple Linear Regression}

Table 3. Multiple Linear Regression Result

\begin{tabular}{ccccc}
\hline $\begin{array}{l}\text { Independent } \\
\text { Variable }\end{array}$ & $\begin{array}{c}\text { Regression } \\
\text { Coefficient }\end{array}$ & $\mathrm{t}$ & $\begin{array}{c}\text { Sig. } \\
\text { (2-tailed) }\end{array}$ & $\begin{array}{c}\text { Sig. } \\
\text { (1-tailed) }\end{array}$ \\
\hline (Constant) & -0.734 & -1.354 & 0.177 & 0.0885 \\
REPUT & -0.323 & -3.614 & 0.000 & $0.000^{*}$ \\
SPEC & -0.194 & -0.697 & 0.486 & 0.243 \\
TENURE & 0.058 & 1.467 & 0.143 & 0.0715 \\
SIZE & 0.068 & 1.472 & 0.142 & 0.071 \\
LEV & -0.027 & -1.913 & 0.056 & 0.028 \\
SEGMENT & 0.018 & 0.920 & 0.358 & 0.179 \\
SUBS & 0.008 & 4.248 & $0.000 *$ & 0.000 \\
DMANUF & -0.075 & -0.643 & 0.521 & 0.2605 \\
DFIN & -0.036 & -0.279 & 0.781 & 0.3905 \\
DSERV & 0.169 & 1.493 & 0.136 & 0.068 \\
DTRADING & 0.113 & 0.812 & 0.417 & 0.2085 \\
\hline
\end{tabular}

Based on the estimated parameter, Equation (5) is: +0.068 SIZE -0.027 LEV + 0.018 SEGMENT + 0.008 SUBS -0.075 DMANUF -0.036 DFIN + 0.169 DSERV -0.056 DTRADING

The F-Test of this model is 0.000 , which is less than 5\%, meaning the independent and control variables simultaneously have a significant impact on the dependent variable. The F-test result also indicates the fitness of the equation model. The adjusted $\mathrm{R}^{2}$ in this study is 0.184 , 
which means that independent and control variables explained $18.4 \%$ of the dependent variables.

Refer to table 3, REPUT had a significant negative impact. It means companies audited by Big 4 have lower restatement amount caused by participation in the tax amnesty program. Meanwhile, the only significant control variable is SUBS. SUBS had a significant positive impact. It means that the higher the number of a subsidiary, the higher the number of restatement amount caused by participation in the tax amnesty program.

\section{4 Analysis and Discussion}

Based on binomial logistic regression, multinomial logistic regression, and multiple linear regression, Auditor's reputation (REPUT) has a significant negative impact on participation in the tax amnesty program.

Binomial logistic regression shows that companies audited by Big 4 had a lower probability in participating the tax amnesty program 0.203 times compare with company audited by nonbig-4. Multinomial logistic regression demonstrates that companies audited by Big 4 had lower probability in participating the tax amnesty program in year 2016, year 2017, and participate in both 2016 and 2017. Lastly, multiple linear regression shows that companies audited by Big 4 have lower restatement amount regarding participation in the tax amnesty program.

This implied that Big 4 public accounting firm produces a higher quality audited financial statement than non-Big 4 public accounting firm. This is because Big 4 auditors are superior in obtaining learning experiences with better skill and knowledge than non-Big 4 auditors, even in short tenure [18]. This leads to them conducting a more in-depth audit and has found all of the clients' assets, including the hidden ones, thus producing a higher quality audited financial statements than non-Big 4 auditors. It is different for non-Big 4 auditors whose audit quality is lower, allowing their clients' hidden asset to remain undisclosed in 2015 audited financial statement and leading their clients to finally uncover the hidden assets whilst participating in the tax amnesty program and restating their 2015 financial statement.

For non-Big 4 clients, it means less or no hidden assets to be revealed in the tax amnesty program because all of the assets are already revealed during the engagement period and disclosed in 2015 audited financial statement. Therefore, it is less likely for companies which audited by Big 4 auditors to participate in the tax amnesty program.

Auditor's industry specialization has no significant impact on participation in the tax amnesty program. Audit tenure also has no significant impact on participation in the tax amnesty program. This is because one until 4 years engagement is not long enough tenure to build a closed relationship between audit partner and client that can cause biases in audit opinion.

\section{Conclusion}

Audit quality measured by auditor's reputation has a significant negative impact on tax amnesty. Companies that were audited by Big 4 in 2015 have a lower probability of participation in the tax amnesty program, participation in tax amnesty program in 2016,2017 , or both, and a lower amount of restatement caused by participation in tax amnesty. This is because Big 4 produces a higher quality audited financial statements. Big 4 are superior in obtaining learning experiences [18]. Big 4 also wanted to protect their reputation from any possible damages, thus leading them to an in-depth audit in the engagement period [11]. 
We also found that leverage had a significant negative impact on participation in the tax amnesty program. The lower the leverage, the more likely the company participates in the tax amnesty program. This is because lower leverage could indicate that company participates in nondebt tax shields [19] [20]. Meanwhile, the subsidiary had a significant positive impact on participation in the amnesty program, participation in tax amnesty program in 2016, 2017, or both, and a lower amount of restatement caused by participation in tax amnesty. This is because there is a possibility of assets hidden in a tax haven that was uncovered in the tax amnesty program.

For further studies, the proxy of audit quality could be varied using other proxies, such as discretionary accruals. Some control variables can also be added to reflect further the dependent variables, such as using foreign subsidiary ownership as an indicator of possible hidden assets that maybe uncovered in a tax amnesty program.

\section{References}

[1] P. Stella*, "an economic analysis of tax amnesties," journal of public economics, vol. 46, pp. 383-400, 1991.

[2] J. M.-v. S. W. James alm, "do tax amnesties work ? The revenue effects of tax amnesties during the transition in the russian federation," economic analysis \& policy, vol. 39, no. 2, pp. 235 253, 2009.

[3] M. J. Pinaki bose, "liberalization and tax amnesty in a developing economy," economic modelling, vol. 29, pp. 761-765, 2012.

[4] I. 200, "international standard on auditing 200 overall objectives of the independent auditor and the conduct of an audit in accordance with international standards on auditing," 2009.

[5] A. J. J.-s. J. T. R. Denise dickins, "selecting an auditor for bradco using indicators of audit quality," journal of accounting education, vol. 45, pp. 32-44, 2018.

[6] J. Reisch, "ideas for future research on audit quality," the auditor's report, vol. Fall, pp. 12-14, 2000.

[7] T.-c. W. Hsin-yi chi, "managerial legal liability and big 4 auditor choice," journal of business research, vol. 67, pp. 1857-1869, 2014.

[8] R. H. T. A. A. D. W. H. Christopher hodgdon, "compliance with international financial reporting standards and auditor choice: new evidence on the importance of the statutory audit," the international journal of accounting , vol. 44, pp. 33-55, 2009.

[9] T. K. W. T. Y. K. Y. Ole-kristian hope, "culture and auditor choice: a test of the secrecy hypothesis," journal of accounting and public policy, vol. 27, pp. 357-373, 2008.

[10] T. V. Z. K. D. A. W. K. Muhammad nurul houqe, "corporate ethics and auditor choiceinternational evidence," research in accounting regulation, vol. 27, pp. 57-65, 2015.

[11] M. L. D. J. J. K. S. Connie 1 becker, "the effect of audit quality on earnings management," contemprary accounting research, vol. 15, no. 1, pp. 1-24, 1998.

[12] B. W. M. Kimberly a. Dunn, "audit firm industry specialization and client disclosure quality," review of accounting studies, vol. 9, pp. 35-58, 2004.

[13] V. N. G. P. W. Robert knechel, "does auditor industry specialization matter? Evidence from market reaction to auditor switches," auditing: a journal of practice \& theory, vol. 26 , no. 1 , pp. 19-45, 2007.

[14] K. H. F. Z. Inaam zgarni, "effective audit committee, audit quality and earnings management," journal of accounting in emerging economics, vol. 6, no. 2, pp. 138-155, 2016.

[15] P. C. Peter carey, "audit partner tenure and audit quality," the accounting review, vol. 81, no. 3 , pp. 653-676, 2006. 
[16] J. V. C. A. A. L. Nagy, "audit firm tenure and fraudulent financial reporting," auditing: a journal of practice \& theory, vol. 23, no. 2, pp. 55-69, 2004.

[17] M. Minutti-meza, "does auditor industry specialization improve audit quality?," journal of accounting research, vol. 51, no. 4, pp. 779-817, 2013.

[18] H. H. Wuchun chi, "discretionary accruals, audit-firm tenure and audit-partner tenure: empirical evidence from taiwan," journal of contemporary accounting \& economics, vol. 1, pp. 65-92, 2005.

[19] R. H. Deangelo, "optimal capital structure under corporate and personal taxation," journal of financial economics, vol. 8, no. 1, pp. 3-29, 1980.

[20] A. L. T. J.r. Graham, "tax shelters and corporate debt policy," journal of financial economics, vol. 81, no. 3, pp. 563-594, 2006. 